\title{
Transaction Processing Software In Principles, Intermediate And Accounting Systems: An Effective Integration Tool
}

John E. Elsea, (E-mail: John.Elsea@unco.edu), University of Northern Colorado John R. Stewart, (E-mail: John.Stewart.edu), University of Northern Colorado

\begin{abstract}
The problem examined in this study is threefold. First, does a review of accounting principles at the beginning of an intermediate accounting course result in a significant improvement in students' understanding of the major processes in the accounting cycle? Second, does the packet of materials, developed by the authors, utilizing a transaction processing approach and an off-theshelf transaction processing application package yield significantly better results on a post-test than teaching the material from an intermediate accounting text? Third, to what extent do students believe the materials developed by the authors are beneficial to them in preparation for intermediate accounting and in introducing them to systems concepts?
\end{abstract}

A review of accounting principles at the beginning of an intermediate accounting course resulted in a significant improvement in students' understanding of the major processes in the accounting cycle regardless of the method of review used in the study. The packet of material developed by the authors utilizing a transaction processing approach and an off-the-shelf transaction processing package yielded similar overall results to using an intermediate textbook review. Overall student responses to the questionnaire were favorable and indicated satisfaction with the instructor prepared review material. Completion of a supplementary problem using additional modules of a transaction processing software program can provide a transition to an accounting systems course.

\section{Introduction}

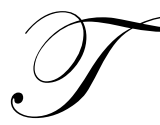

he influence of groups such as the Bedford Committee and the Accounting Education Change Commission (AECC) has caused a trend away from the traditional accounting curriculum and the traditional methods of instruction toward an approach of introducing concepts before rules. This was first apparent in accounting principles courses, and was later implemented in some intermediate accounting courses and curriculum. For example, several universities including the University of Virginia (Catanach, Croll, Grinaker, 2000) and Villanova University (Catanach, 2001) have adopted a business activity model (BAM). In this model, students work in teams to perform real word activities for a fictitious client company. Many other universities continue to offer intermediate accounting in the more traditional format. Regardless of the format used, it does appear that some review of principles of accounting is desirable if not necessary. Intermediate accounting textbooks reflect this need by including a review somewhere in the text, usually in an appendix. In the schools using the BAM approach, the first five weeks of the revised course sequence is used to review the fundamentals of financial accounting. (Catanach, Croll, Grinaker, 2000)

Although there is little time in intermediate accounting courses to review principles of accounting, the authors believe it is essential that students understand how information gets from the transaction into the financial 
statements. In their article the Boyds state, "No student, accounting major or otherwise, can grasp the implications of the work the accountant performs and how to use the resulting financial statements without understanding (a) the accounting cycle, and (b) the financial statements and their accounts." (Boyd, Boyd and Boyd, 2000) Deines contends that foundation level courses detail how the accounting system works as well as the theory and history of accounting standards. (Deines, 2002) Transaction processing or general ledger applications take some of the mechanical, repetitious, error prone routines out of this process. The use of this type of software also promotes the introduction of systems concepts at the principles and intermediate course level.

To assess students' understanding of the accounting cycle the authors developed a problem type exam that included analyzing and recording transactions, the trial balance, adjusting entries, closing entries and the financial statements. Copies of the examination used for this study are available upon request from the authors. The examination was used as a pre-test to determine students' weaknesses, and as a post-test to determine students' progress. The topics on the examination are similar to those tested with a diagnostic exam given by Danko-McGhee and Duke. (Danko-McGhee and Duke,1992)

\section{The Problem}

The problem examined in this study is threefold. First, does a review of accounting principles at the beginning of an intermediate accounting course result in a significant improvement in students' understanding of the major processes in the accounting cycle? The null hypothesis is there is no significant difference between the pretest and post-test results. Second, does the packet of materials, developed by the authors, utilizing a transaction processing approach and an off-the-shelf transaction processing application package yield significantly better results on a post-test than teaching the material from an intermediate accounting text? The null hypothesis is there is no significant difference between the control and experimental groups on the post-test. Third, to what extent do students believe the materials developed by the authors are beneficial to them in preparation for intermediate accounting and in introducing them to systems concepts?

\section{Methodology}

During the fall semester of 2001 a review of principles of accounting was completed with a control group consisting of two Intermediate Accounting classes. They were taught by a lecture/discussion method that focused on the material covered in an appendix to the text, Intermediate Accounting, $8^{\text {th }}$ edition, by Nikolai and Bazley. On the second day of class students were given a problem type pre-test consisting of five parts: general journal entries for transactions with external parties, adjusting journal entries, the trial balance, closing entries and classifying accounts on the financial statements. The pre-test was written by one of the authors and reviewed for content by the other author. Students were given the resulting scores by section on the pre-test, but were never given an opportunity to see the exam. Upon completion of the review the same examination was given as a post-test.

During the Spring and Fall Semesters of 2002 and the Spring Semester, 2003 a review of principles of accounting was completed with an experimental group of six Intermediate Accounting classes. They were taught by a lecture/discussion method that focused on a packet of materials written by the authors. Problems were also assigned from the appendix in the text. The packet of materials consisted of the following:

- An introduction and overall review of accounting principles emphasizing definitions and the financial statements.

- $\quad$ Analyzing transactions using the expanded accounting equation (spreadsheet) format and recording a variety of transactions and adjustments in excel.

- $\quad$ Using a manual double entry accounting system to record the same transactions in general journal form and to complete the steps in a manual accounting system from journal entry to post closing trial balance. The packet included dialogue explaining the manual system.

- Instructions for using the general module of Simply Accounting V8.5 for windows and a practice problem utilizing the general module. (Simply 2001) 
- $\quad$ Entering the same transactions that had been used for the expanded accounting equation and manual system into the general module.

- $\quad$ Completing a project consisting of 18 transactions and 8 adjustments to be handed in for grading.

- $\quad$ Encouraging students to continually view journal entries, ledger accounts and financial statements as they input the transactions into the general module.

On the second day of class students were given the same pre-test that had been administered to the control group. Students were given the resulting scores by section on the pre-test, but were never given an opportunity to see the exam. Upon completion of the review the same examination was given as a post-test. At the end of the semester students in the experimental group completed a questionnaire regarding the value of:

- $\quad$ a review of accounting principles

- the text appendix

- $\quad$ the review packet developed by the authors

- $\quad$ and a supplementary problem involving the use of other modules of the transaction processing software to introduce additional systems concepts.

The instructor prepared material and the appendix was only used by the experimental group. Therefore, it was the only group that could make a comparison.

\section{Results}

as:

The components of the pretest and posttest examinations are displayed in Tables I - III. They are described

- $\quad$ Reg Ent $=$ Manually recording of journal entries to capture transactions between a company and outside parties.

- $\quad$ Adj Ent = Manually recording a variety of accrual and deferral adjustment entries commonly covered in principles courses.

- $\quad$ Trial Balance $=$ From a listing of randomly arranged accounts with normal balances students manually prepared a Trial Balance.

- $\quad$ Clo Ent $=$ Manually recording journal entries to close the temporary owner equity accounts.

- $\quad$ Fin Stmts = Students were asked to identify the financial statement, classify the accounts properly, and specify the normal balance of a listing of accounts.

- $\quad$ Total $=$ All the above parts combined score.

The pretest results were used to determine the equality of the control and experimental groups at the beginning of the semester. Table I indicates that overall there was no significant difference between the groups at the .05 level (P Value .4900). However there was a significant difference for two of the components, regular journal entries and closing entries (P Values .0026 and .0068 respectively). This is discussed as the posttest results are examined.

Table I: Equality Of Groups

\begin{tabular}{|l|c|c|c|c|c|c|c|}
\hline Averages by Group & $\mathbf{n}$ & Reg Ent & Adj Ent & Trial Bal & Clo Ent & Fin Stmts & Total \\
\hline Control Pretest & 57 & 5.90 & 3.39 & 3.34 & 2.58 & 8.89 & 24.10 \\
\hline Experimental Pretest & 117 & 6.87 & 3.04 & 3.33 & 1.65 & 9.24 & 24.13 \\
\hline TTest P Values & $* .0026$ & .1849 & .4881 & $* .0068$ & .1582 & .4900 \\
\hline
\end{tabular}

* Significant at the .05 level 
One of the expected results of this study was that a review of accounting principles at the beginning of an intermediate accounting course would result in a significant improvement in students' understanding of the major processes in the accounting cycle. The results reported in Table II indicate that this was true. In every case there was a significant difference between the pretest and posttest results and therefore the null hypothesis was rejected. Either method of review used in this study proved beneficial to students entering intermediate accounting.

Table II: Effect Of Reviewing The Accounting Cycle

\begin{tabular}{|l|c|c|c|c|c|c|c|}
\hline Averages by Group & $\mathbf{n}$ & Reg Ent & Adj Ent & Trial Bal & Clo Ent & Fin Stmts & Total \\
\hline Control Pretest & 57 & 5.90 & 3.39 & 3.34 & 2.58 & 8.89 & 24.10 \\
\hline Control Posttest & 57 & 8.00 & 7.65 & 6.36 & 6.86 & 11.32 & 40.19 \\
\hline TTest P Values & $* .0000$ & $* .0000$ & $* .0000$ & $* .0000$ & $* .0000$ & $* .0000$ \\
\hline \multicolumn{7}{|l|}{} & \multicolumn{5}{l|}{} \\
\hline Experimental Pretest & 117 & 6.87 & 3.04 & 3.33 & 1.65 & 9.24 & 24.13 \\
\hline Experimental Posttest & 117 & 9.57 & 7.18 & 5.90 & 5.50 & 11.65 & 39.80 \\
\hline TTest P Values & $* .0000$ & $* .0000$ & $* .0000$ & $* .0000$ & $* .0000$ & $* .0000$ \\
\hline \multicolumn{2}{|l|}{} & & & & & & \\
\hline All Students Pretest & 174 & 6.55 & 3.16 & 3.33 & 1.96 & 9.12 & 24.12 \\
\hline All Students Posttest & 174 & 9.06 & 7.33 & 6.05 & 5.95 & 11.54 & 39.93 \\
\hline TTest P Values & & $* .0000$ & $* .0000$ & $* .0000$ & $* .0000$ & $* .0000$ & $* .0000$ \\
\hline
\end{tabular}

* Significant at the .05 level

A focal point of the experiment was to determine if the packet of materials, developed by the authors, utilizing a transaction processing approach and an off-the-shelf transaction processing package would yield significantly better results on a post-test than teaching the material from an intermediate accounting text. The results reported in Table III indicate that overall there was no significant difference between the means of the two groups. Therefore the null hypothesis was retained. There was a significant difference for three of the five components: regular journal entries, trial balance, and closing entries. These differences can be partly explained as follows:

- $\quad$ Students in the experimental groups who used the instructor prepared transaction processing software analyzed and input the journal entries very carefully. They were encouraged to "do it once and do it right". In the instructor provided material students were taught to prepare entries manually and on the computer. This emphasis may have caused the means between the groups for regular journal entries to be significantly different in favor of the experimental group.

- Students in the experimental group relied on the computer software to prepare the trial balance and complete the closing process automatically. This may have caused the means between the groups for trial balance and closing entries to be significantly different in favor of the control group.

It should be emphasized that regardless of the treatment both groups benefited from a review of the accounting cycle. The results indicate that a review utilizing the authors' material and transaction processing software enhances students' ability to record regular journal entries. However, there is a need to supplement the use of the computer with manual coverage of those functions the computer does automatically.

Table III: Comparison Of Experimental And Control Groups

\begin{tabular}{|l|l|l|l|l|l|l|c|}
\hline \multicolumn{1}{|c|}{ Averages by Group } & \multicolumn{1}{c|}{$\mathbf{n}$} & \multicolumn{1}{c|}{ Reg Ent } & Adj Ent & \multicolumn{1}{c|}{ Trial Bal } & Clo Ent & Fin Stmts & Total \\
\hline Control Posttest & 57 & 8.00 & 7.65 & 6.36 & 6.86 & 11.32 & 40.19 \\
\hline Experimental Posttest & 117 & 9.57 & 7.18 & 5.90 & 5.50 & 11.65 & 39.80 \\
\hline TTest P Values & $* .0000$ & .0590 & $* .0321$ & $* .0000$ & .0974 & .3476 \\
\hline
\end{tabular}

* Significant at the .05 level 
A questionnaire was administered to the students in the experimental group after the material in the packet was completed. Demographic information revealed that students completed their Principles of Accounting I and II courses at the educational institutions listed in Table IV.

Table IV: Schools Where Accounting Principles Were Completed

\begin{tabular}{|l|c|c|}
\hline Schools & Prin I & Prin II \\
\hline (university of research) & 89 & 96 \\
\hline Community Colleges & 22 & 20 \\
\hline Other Domestic Universities & 8 & 4 \\
\hline Foreign Universities & 2 & 0 \\
\hline No Response & 1 & 2 \\
\hline Total & 122 & 122 \\
\hline
\end{tabular}

The grades received by the respondents in Principles I and II courses are disclosed in Table V.

Ninety respondents indicated they were Juniors, and 32 were Seniors. Of the 122 respondents 53 were females and 59 were males. A breakdown by major is reported in Table VI.
Table VI: Students By Major

\begin{tabular}{|l|c|}
\hline Major & Number \\
\hline Accounting & 75 \\
\hline Accounting/Finance & 5 \\
\hline Accounting/CIS & 1 \\
\hline Accounting/Management & 3 \\
\hline Finance & 28 \\
\hline Finance/CIS & 1 \\
\hline Finance/Marketing & 1 \\
\hline CIS/Marketing & 1 \\
\hline Marketing & 1 \\
\hline General Business & 3 \\
\hline Management & 1 \\
\hline Dietetics & 1 \\
\hline Economics & 1 \\
\hline Total & 122 \\
\hline
\end{tabular}

Table V: Grades By Course

\begin{tabular}{|l|c|c|}
\hline Grades & Prin I & Prin II \\
\hline A & 53 & 39 \\
\hline B & 45 & 56 \\
\hline C & 24 & 27 \\
\hline Total & 122 & 122 \\
\hline
\end{tabular}

The number of students responding to the questionnaire ranged from $122-118$. The responses to the 22 statements regarding the value of a review of accounting principles, the text appendix and the review packet developed by the authors and the introduction of systems concepts are summarized in Table VII.

A five point Likert scale was used where $1=$ Strongly Disagree, 2 = Disagree, 3 = Undecided, $4=$ Agree, and $5=$ Strongly Agree. Table VII collapses choices 1 and 2 into Disagree, 4 and 5 into Agree and Undecided responses are omitted. The Undecided responses are included in the calculation of the reported means.

Although many students indicated they felt they understood the accounting cycle (55\% on item 3 ) their responses to items 4 and 5 show a strong belief ( $91 \%$ and $72 \%$ respectively) that both the instructor prepared packet and the text appendix provided an excellent review of accounting principles.

Respondents felt the instructor prepared packet:

- Helped them analyze and record business transactions as well as understand the relationship of transactions to the financial statements. (Item $1-90 \%$, Item $8-84 \%$, and Item $11-69 \%$ )

- $\quad$ Provided an excellent review of principles of accounting (Item $4-91 \%$ )

- Was easy to understand (Item $10-85 \%$ )

- Helped them develop a basic understanding of transaction processing software (Item 12-90\%)

- $\quad$ Stimulated student interest to learn more about accounting information systems (Item $14-60 \%$ ) 
The text appendix also helped respondents review principles of accounting and understand the relationship of transactions to the financial statements but to a lesser degree than the instructor prepared packet. (Item $5-72 \%$ and Item $2-78 \%$ )

Table VII: Questionnaire Responses

\begin{tabular}{|c|c|c|c|}
\hline Question & Disagree & Agree & Mean \\
\hline $\begin{array}{l}\text { 1. Using the packet helped me develop an understanding of the relationship of } \\
\text { transactions to the financial statements. }\end{array}$ & $5.74 \%$ & $90.16 \%$ & 4.14 \\
\hline $\begin{array}{l}\text { 2. Using the material in Appendix } \mathrm{C} \text { helped me develop an understanding of the } \\
\text { relationship of transactions to the financial statements. }\end{array}$ & $6.56 \%$ & $77.87 \%$ & 3.92 \\
\hline $\begin{array}{l}\text { 3. I never really understood the complete accounting cycle until I completed the } \\
\text { packet. }\end{array}$ & $54.92 \%$ & $23.77 \%$ & 2.64 \\
\hline 4. The packet provided an excellent review of Principles of Accounting. & $3.31 \%$ & $90.91 \%$ & 4.33 \\
\hline 5. Appendix C provided an excellent review of Principles of Accounting. & $13.22 \%$ & $71.90 \%$ & 3.76 \\
\hline $\begin{array}{l}\text { 6. I would have had trouble understanding Intermediate Accounting I without a } \\
\text { review. }\end{array}$ & $6.61 \%$ & $83.47 \%$ & 4.21 \\
\hline 7. We should not review Accounting Principles in this course. & $95.87 \%$ & $2.48 \%$ & 1.37 \\
\hline $\begin{array}{l}\text { 8. Using the packet helped me understand how to analyze and record business } \\
\text { transactions. }\end{array}$ & $8.26 \%$ & $84.30 \%$ & 3.95 \\
\hline $\begin{array}{l}\text { 9. Appendix } \mathrm{C} \text { helped me understand how to analyze and record business } \\
\text { transactions. }\end{array}$ & $13.33 \%$ & $70.00 \%$ & 3.67 \\
\hline 10. The material in the packet was easy to understand. & $6.61 \%$ & $85.12 \%$ & 4.17 \\
\hline $\begin{array}{l}\text { 11. I frequently looked at the financial statement reports while doing the computer } \\
\text { projects. }\end{array}$ & $19.83 \%$ & $68.60 \%$ & 3.69 \\
\hline $\begin{array}{l}\text { 12. By using SIMPLY PRO V8 I have developed a basic understanding of } \\
\text { transaction processing software. }\end{array}$ & $1.65 \%$ & $90.08 \%$ & 4.12 \\
\hline 13. I enjoyed using the computer during the first three weeks. & $12.40 \%$ & $74.38 \%$ & 3.82 \\
\hline $\begin{array}{l}\text { 14. Using the computer in this class has stimulated my interest to learn more about } \\
\text { accounting systems. }\end{array}$ & $14.05 \%$ & $60.33 \%$ & 3.65 \\
\hline \multicolumn{4}{|c|}{$\begin{array}{l}\text { The last computer project completed in this course introduced the purchases, sales, receipts, payments and payroll modules in } \\
\text { SIMPLY PRO V8 and systems concepts. The following items address student responses about this material. }\end{array}$} \\
\hline $\begin{array}{l}\text { 15. By using these modules I learned that documents and journal entries are often } \\
\text { prepared at the same time. }\end{array}$ & $5.83 \%$ & $85.00 \%$ & 3.92 \\
\hline $\begin{array}{l}\text { 16. I found it is important to plan the preparation of journal entries before they are } \\
\text { posted. }\end{array}$ & $.83 \%$ & $98.33 \%$ & 4.34 \\
\hline $\begin{array}{l}\text { 17. I developed an understanding of payroll accounting by using the payroll } \\
\text { module. }\end{array}$ & $6.67 \%$ & $83.33 \%$ & 3.97 \\
\hline 18. These modules helped me develop an understanding of perpetual inventories. & $11.02 \%$ & $69.49 \%$ & 3.67 \\
\hline $\begin{array}{l}\text { 19. By using the purchases module I have developed an appreciation of the } \\
\text { complexities in using the net method of recording purchases. }\end{array}$ & $6.78 \%$ & $79.66 \%$ & 3.94 \\
\hline $\begin{array}{l}\text { 20. By using these modules I developed an understanding of how customer and } \\
\text { vendor subsidiary accounts are maintained. }\end{array}$ & $3.39 \%$ & $85.59 \%$ & 3.97 \\
\hline $\begin{array}{l}21 . \text { I occasionally looked at the subsidiary ledger accounts while doing this } \\
\text { project. }\end{array}$ & 14.41 & $62.71 \%$ & 3.60 \\
\hline 22. I came to appreciate the statement, "Enter it once and enter it right" & $4.24 \%$ & $93.22 \%$ & 4.38 \\
\hline
\end{tabular}

In addition respondents believed that a review of principles of accounting is essential for success in intermediate accounting (Item $6-83 \%$ and Item $7-2 \%$ ).

Items 15 - 22 relate to the use of modular transaction processing software to introduce accounting systems concepts into the first intermediate accounting course. They solicit students' perceptions of their understanding of topics and applications that will be further developed in accounting systems. The responses to these statements were all positive ranging from $98 \%$ to $63 \%$. 


\section{Conclusions}

A review of accounting principles at the beginning of an intermediate accounting course resulted in a significant improvement in students' understanding of the major processes in the accounting cycle regardless of the method of review used in the study. The importance of a review was also supported by responses on a student questionnaire.

The packet of material developed by the authors utilizing a transaction processing approach and an off-theshelf transaction processing package yielded similar overall results to using an intermediate textbook review. Use of this material produced better results for analyzing and recording daily journal entries and less favorable results for preparing a trial balance and the closing process.

Overall student responses to the questionnaire were favorable and indicated satisfaction with the instructor prepared review material. Completion of a supplementary problem using additional modules of a transaction processing software program can provide a transition to an accounting systems course.

\section{References}

1. Boyd, D. T., Boyd, S. C., \& Boyd, W. L. (2000). Changes in Accounting Education: Improving Principles Content or Better Understanding. Journal of Education for Business, 76(1), 36-43.

2. Catanach, A. H. (2001). The Business Activity Model: A new Approach to Intermediate Financial Accounting. Pennsylvania CPA Journal, 72(1) 22.

3. Catanach, A. H., Croll, D. B., \& Grinaker, R. L. (2000). Teaching Intermediate Financial Accounting Using a Business Activity Model. Issues in Accounting Education, 15(4), 583-604.

4. Danko-McGhee, K. \& Duke, J. C. (1992). Predicting Student Performance in accounting Classes. Journal of Education for Business, 67(5) 270-275.

5. $\quad$ Deines, D. (2002). Beyond The "Old School." Journal of Accountancy, 194(3), 68-70.

6. Nikolai, L. \& Bazley, J. (2000). Intermediate Accounting, $8^{\text {th }}$ edition, South-Western College Publishing.

7. Simply Accounting Pro, Version 8.5, 2001, ACCPAC International Inc.

Notes 
Notes 